\title{
Legal Security for Patients Using the Health Social Security Administering Bodies Card
}

\author{
Nana Sarnadi ${ }^{1}$, Faisal Santiago ${ }^{2}$ \\ Borobudur University ${ }^{1,2}$ \\ \{nanasarnadi88@gmail.com¹, faisalsantiago@borobudur.ac.id²
}

\begin{abstract}
This paper discusses legal guarantees related to patients' rights using the Health Social Security Administering Bodies (BPJS) cards. By using normative juridical research methods and data analysis derived from existing literature and regulations, it is found that the Government has guaranteed and established regulations that provide guarantees and protection to patients using Social Health Security Administrators (BPJS). It is necessary to do socialization and education both to the hospital and patients so that the rules that have been set are appropriately implemented.
\end{abstract}

Keywords Legal Guarantee; Patient; BPJS

\section{Introduction}

Indonesia is a developing country. The problem faced by developing countries, especially Indonesia, is a health problem. Health is the fundamental right of every individual, and all citizens are entitled to health services, including the poor. Article $28 \mathrm{H}$ paragraph (3) of the 1945 Constitution states that "everyone is entitled to social security that allows the development of himself or herself as a dignified human being." The health problems present in Indonesia today are very diverse and must be addressed immediately with strong cooperation between the Government, the community, and hospitals. Cooperation between the Government, the community, and the hospital is realized by establishing various health services by the Government.

Quality health services will produce maximum health and create people's lives away from disease. Social security is reviewed from a Human Rights perspective (from now on referred to as human rights). Human rights are a set of rights inherent in man's nature and existence as a being created by The One True God. Therefore, one of the inherent rights to protecting human dignity and dignity is the right to social security. It must be protected, respected, and upheld by the state, the Law, the Government, and the individual. In Indonesia, philosophy, and Pancasila, especially the 5th precept, recognizes citizens' human rights over health. This right to health means that the Government is obliged to create conditions that allow each individual to live a healthy life. This is done by providing adequate health care facilities and affordable health services for the community.

As referred to in the Preamble to the 1945 Constitution, the national objective is to protect the entire Nation of Indonesia and all Indonesian bloodshed, promote the general welfare, educate the nation's life, and participate in maintaining world order and social justice. The 
opening of the Constitution of the Republic of Indonesia year 1945 mandated that the purpose of the state is to improve people's welfare. In the Fourth Amendment of the Constitution of the Republic of Indonesia in 1945, the objective was further affirmed by developing a social security system for all people's welfare. [1] The right to an adequate degree of life for the health and well-being of himself and his family is a human right and is recognized by all nations globally, including Indonesia.

A derivative of the 1945 Constitution on social security is in Law No. 40 of 2004on, the National Social security system. With the Law, the Indonesian nation already has a Social Security system for all Indonesians. To realize the purpose of the national social security system needs to be established an organizing body in the form of a public legal entity based on the principle of mutual cooperation, non-profit, openness, prudence, accountability, portability, compulsory participation, mandate funds, and the results of the management of social security funds are used entirely for the development of the program and the maximum interests of participants. Law No. 24 of 2011, while the Social Security Organizing Agency (BPJS) also stipulates, National Social Security will be organized by BPJS, which consists of BPJS Health and BPJS Employment.

Especially for National Health Insurance (JKN) will be organized by BPJS Health implementation starting January 1, 2014. Operationally, the implementation of JKN is outlined in government regulations and presidential regulations, including Government Regulation No. 101 of 2012 concerning Beneficiaries of Contribution Assistance (PBI); Presidential Regulation No. 12 of 2013 on Health Insurance. The establishment of the Law on Social Security Administering Bodies is the implementation of Law No. 40 of 2004 on the National Social Security System, after the Constitutional Court's Decision on the case No. 007/PUU-III/2005, in order to provide legal certainty for the establishment of BPJS to implement social security programs throughout Indonesia. This Law is the implementation of Article 5 paragraph (1) and Article 52 of Law No. 40 of 2004 concerning the National Social Security System that mandates the establishment of a Social Security Organizing Body and institutional transformation of PT Askes (Persero), PT Jamsostek (Persero), PT TASPEN (Persero), and PT ASABRI (Persero) into a Social Security Organizing Body. [2]

The Government's efforts to carry out its obligations include creating a social security system called National Health Insurance (from now on abbreviated as JKN). JKN is a guarantee in the form of health protection so that participants get health care benefits and protection in meeting primary health needs provided to everyone who has paid dues or dues paid by the Government. JKN is the description of the 1945 Constitution, and this is one of the strong evidence that the Government has a significant commitment to realizing social welfare for the whole community. The Government's efforts to implement a comprehensive social security system for Indonesia's people include establishing a Social Security Organizing Agency (from now on abbreviated as BPJS). The Government stipulates that BPJS will organize national social security for all Indonesians. [3] This paper will examine how the legal protection of patients who are participants of BPJS.

\section{Method}

This paper is normative juridical research that examines the prevailing laws and regulations. Using literature as data is then analyzed using descriptive analysis. Questions related to legal protection for patients participating in the Social Security Administering Agency will be answered descriptively from the results of the data analysis found from 
searches of existing literature. Thus it is expected that the answers to research problems will be answered comprehensively.

\section{Discussion}

Social security is the protection provided by the community to its members for specific risks or events for the purpose, to the extent possible, to avoid such events that may result in the loss or loss of most income and to provide medical or financial security services to the economic consequences of such events, as well as guarantees for family and child support. [4] The BPJS social security program is divided into five types of social security programs and implementation made in 2 organizing programs, namely:

a. The program organized by BPJS Kesehatan, with its program is Health Insurance, valid from January 1, 2014.

b. The program is organized by BPJS Ketenagakerjaan, with its program is Work Accident Guarantee, Old Age Guarantee, Pension Guarantee, and Death Insurance planned to start from July 1, 2015.

Social Security organizers are shaped like insurance, and later all Indonesian citizens are required to join this program. In participating in this program, BPJS participants are divided into two groups, namely for able communities and underprivileged community groups. Participants of the BPJS group are two groups, namely[3]:

a. PBI (from now on referred to as Beneficiary Contributions) health insurance, namely PBI, is a participant of Health Insurance for the poor and the poor as mandated by the SJSN Law. The Government pays Their dues as participants of the Health Insurance program. PBI participants are poor people who are determined by the Government and regulated through Government Regulations

b. Not PBI health insurance. [5]

The classification is based on the economic strata in the community. People who can afford it pay a certain amount of money each month to enjoy health facilities when they are sick. For underprivileged people, the dues they are supposed to pay will be borne by the state. The data collection of underprivileged communities was done to the local Government assisted by Rukun Tetangga. The data collection is done to see the income and economic level. The resulting data's validity becomes the Government's duty to do kroscek and bear all costs incurred by the Government to pay dues and bear every underprivileged community.

Factually, there are still differences and differences in facilities related to health services received for the community covered by the Government with bpjs paid by themselves. [6] Conceptually, every society is a consumer of BPJS, so the health services received are appropriately equal and uphold the principle of justice. By Article 1 point 1 of the Consumer Protection Law, legal protection for consumers is all efforts that ensure legal certainty to protect consumers. Legal certainty to protect consumers is to bind consumers' dignity and dignity and open access to information about goods and / services for them and develop an honest and responsible attitude of business actors.

Based on Law No. 8 of 1999 concerning Consumer Protection, Article 4, number 3 states that consumers, in this case, our patients have the right to correct, transparent, and honest information about the conditions and warranties of goods and services. If you look at the above problems, all the patient's rights as a consumer have not been fulfilled. [7] In this case, patients as consumers of health care services are reluctant to discuss such problems. They accept whatever the hospital decides. Patients as consumers should be more conscientious and 
be smart consumers in accepting their rights. As connoisseurs of hospital services, patients get respect for human rights that are harmed against them and get legal protection given to the community to enjoy all the rights granted by the Law. Law No. 44 of 2009 concerning Hospitals Article 32 states that every patient has the right to obtain information about patients' rights and obligations. If you look at the article's content above, all human rights of patients should have been fulfilled, but in everyday life, many of patients' rights are ignored.

BPJS Healthcare patients in this regard as consumers have not fully become smart consumers. [8] Without clear information obtained from the hospital, the patient as a consumer does not have any handle that makes him feel protected in case of anything untoward. They prefer to submit to what befalls them in the future. As a consumer, patients prefer instant administration that does not take much time to complete, so they have to go back and forth repeatedly.

The patient who wants to follow up on the disease is first asked for approval. In this case, it is called a therapeutic transaction agreement established between the hospital/doctor and the patient. This agreement is an agreement made for the patient's recovery. If everything happens to the patient, the doctor, to misdiagnosis cases that harm the patient, will be taken to the Honorary Council of Medical Ethics (MKEK) under the auspices of the Indonesian Doctors Association (IDI), both at the central level and at the branch level to determine whether or not mistakes were made. So, the doctor who determines whether or not a doctor is guilty of the patient is a unique institution called MKDKI (Honorary Majelis of Indonesian Medical Discipline).

As it is known that the form of legal protection for a patient is entitled to compensation due to mistakes or omissions committed by health workers. The granting of this right to indemnity is an effort to protect everyone for any consequences arising, both physical and non-physical, due to mistakes or omissions of health workers. This form of protection is essential because as a result of negligence or error, it may cause death or cause permanent disability. Therefore, it is necessary to ensure legal protection by applicable laws and regulations to provide a sense of security and comfort to every community as consumers of BPJS Kesehatan.

Law as a form of real protection for anyone. Justice is the ultimate goal that the Law itself can give. In addition to legal certainty and the usefulness of the Law, justice is the final value that must be achieved to create balance. [6] Therefore, there needs to be a balance between policymakers and policy recipients. In this case, it is a balance that must be maintained between BPJS, hospitals (doctors), and patients. A doctor as a professional manager must always be responsible for carrying out his profession. Because the doctor's responsibility in carrying out his duties as medical personnel is comprehensive, the doctor must also understand and understand the legal provisions that apply to his profession's implementation.

Legal protection of BPJS user patients is all efforts that ensure the existence of legal certainty to protect patients who use BPJS. This can be seen from the implementation of health services, including the implementation of patient rights and obligations, hospital accountability as an organizer in health services for patients, and legal efforts that can be done by patients using BPJS. Patients have generally protected in the Health Law and also the Consumer Protection Law. In contrast, patients who use BPJS and being given legal protection under the Health Law and the Consumer Protection Law also refer to Law No. 40 of 2004 on the National Social Security System and Law No. 24 of 2011 on Social Security Administering Bodies. To create legal protection for patients, the parties must understand the rights and obligations attached to them, including health care providers, to be responsible for the profession provided to the recipients of health care services. [9] 
The Law protects the right to obtain health services for the community. This is part of the implementation of the protection of human rights that has been mandated in the Constitution of the Republic of Indonesia year 1945. As a legal measure that guarantees protection for patients, patients have the right to be fulfilled to obtain health services that apply to everyone through health facilities such as government hospitals to provide safe, quality, and affordable health services. [10] The fulfillment of this right to obtain proper health services through health facilities in government hospitals is guaranteed and implemented by the government or local governments to ensure the availability of all forms of quality, safe, efficient, and affordable health efforts. Although the Government is responsible for improving public health, community participation is still needed to fulfill public health rights following human rights values.

\section{Conclusion}

Through the Minister of Health, the Government has established several regulations governing the implementation of the BPJS health program both on tariffs and procedures in obtaining health services. In the regulation so that participants are not collected when utilizing their right to get services. In contrast, BPJS health has prepared officers in each hospital to escort and accompany and provide services to participants in utilizing their right to treatment in designated health facilities. Socialization and education are required to the community to understand the accompanying legal guarantees and protect them as patients from participants of the Social Security Organizing Agency. When there are different treatment and injustices, it can straighten and demand justice based on the prevailing laws and regulations to feel comfort and security. Social security that is evenly distributed and protected by the Law is by the mandate of the 1945 constitution, namely to improve people's lives.

\section{Reference}

[1] E. Hidayat, "Protection of Human Rights in the State of Indonesian Law," Asas J. Huk. and Ekon. Islam, vol. 8, no. 2, pp. 80-87, 2016, [Online]. Available: https:/www.neliti.com/publications/56534/perlindungan-hak-asasi-manusia-dalamnegara-hukum-indonesia.

[2] Z. Zulliati, "Analysis of Patient Satisfaction of BPJS Participants to the Quality of Maternity Care Services at Dr. H. Moch Hospital. Ansari Saleh Banjarmasin," Proceeding Sari Mulia Univ. Midwifery Natl. Semin. , no. 1, pp. 274-289, Jul. 2019, DOI: $10.33859 /$ psmumns.v0i1.51.

[3] S. S. Atin Wirantika*, "IMPLEMENTATION OF LEGAL PROTECTION FOR WORKERS / WORKERS BPJS HEALTH PARTICIPANTS IN SERVICES IN BHAYANGKARA INDRAMAYU HOSPITAL," Diponegoro Law Rev. , 2016.

[4] Z. Asyhadie, Aspects of Labor Social Security Law in Indonesia. Mataram: Rajawali Pers, 2007.

[5] BM. Sholehah, U. Sudjana, and A. Suryaman, "PROTECTION OF PATIENTS IN HEALTH SERVICES BY BPJS HEALTH FACILITIES IN BANDUNG are CONNECTED WITH LAW NO. 24 OF 2011 CONCERNING SOCIAL SECURITY ADMINISTERING BODIES AND REGULATION OF THE MINISTER OF HEALTH NO. 71 OF 2013 CONCERNING K SERVICES," Hermeneut. J. Huk 
Science. , vol. 4, no. 1, Feb. 2020, doi: 10.33603/hermeneutics.v4i1.3275.

[6] B. Anzward and M. Muslaini, "The Principle of Justice in the Fulfillment of The Rights of Patients Receiving Contributions from the Health Social Security Agency," $J$. Facto, 2019.

[7] Z. Zulliati, "Analysis of Patient Satisfaction of BPJS Participants to the Quality of Maternity Care Services at Dr. H. Moch Hospital. Ansari Saleh Banjarmasin," Proceeding Sari Mulia Univ. Midwifery Natl. Semin. , 2019, DOI: 10.33859/psmumns.v0i1.51.

[8] S. Hartati, T. Haryadi, and O. Hartati, "Legal Protection of Patient Rights of Bpjs Participants," HUK PROTECTION. PATIENT RIGHTS OF BPJS Kesehat PARTICIPANTS. AT RSUD KAB. BREBES,2015.

[9] F. Firdaus, "Patient Protection in the Era of BPJS Health," Ijtihad, 2019, DOI: 10.15548/ijt.v34i2.10.

[10] E. R. Pratiwi, M. Syahbandir, and A. Yahya, "Legal Protection of Patient Rights of Users of Social Security Organizing Body Class 3," Syiah Kuala Law J. , vol. 1, no. 1, pp. 119-139, Nov. 2018, DOI: 10.24815/sklj.v1i1.12270. 